\title{
MRI based non-invasive detection of cardiomyocyte hypertrophy and cell-volume changes
}

\author{
Otavio R Coelho-Filho ${ }^{2,1^{*}}$, Richard N Mitchell2, Heitor Moreno1', Raymond Kwong ${ }^{2}$, Michael Jerosch-Herold ${ }^{3}$ \\ From 15th Annual SCMR Scientific Sessions \\ Orlando, FL, USA. 2-5 February 2012
}

\section{Summary}

A new approach has been developed to detect myocardial cell-hypertrophy, by measuring the intra-cellular lifetime of water in a mouse model of hypertensive heart disease, and validating the MRI marker against measurements of cell dimensions on stained heart slices.

\section{Background}

Cardiomyocyte hypertrophy occurs in cardiomyopathies and in response to pressure overload. However, only endomyocardial biopsies allow detection, with the inherent risks of invasive catheter-based procedures. Noninvasive detection of cardiomyocyte hypertrophy using imaging may detect disease at a subclinical stage and potentially guide therapy. To-date, no imaging-technique has been validated to detect hypertrophic response at the cellular level. We developed a novel measure of cell size based on the MRI determination of the intra-cellular lifetime ( $\tau$ ic) of water, using pre/post-contrast T1 measurements and a 2-site $\mathrm{H}$-exchange model (2SXmodel). We hypothesized that $\tau$ ic correlates positively with the histological measure of cardiomyocyte volume (Vic) in a rodent model of hypertensive heart disease.

\section{Methods}

L-NAME $(3 \mathrm{mg} / \mathrm{ml})$ or placebo were administered respectively to $17(\mathrm{bw}=37.2 \pm 2.3 \mathrm{~g})$ and $13(\mathrm{bw}=37.5$ $\pm 2.5 \mathrm{~g})$ male-wild-type mice. Mice were imaged at baseline and 7-weeks after treatment on a 4.7T-small-animal MRI-system. T1 (>5T1 measurement/mouse) was quantified with a modified Look-Locker gradient-echo-cine technique, before and after fractionated Gadolinium-

\footnotetext{
${ }^{2}$ Medicine, Brigham and Women's Hospital, Boston, MA, USA Full list of author information is available at the end of the article
}

DPTA administration. Minor (Dmin) and major (Dmaj) cell-diameters were measured by FITC-labeled wheat germ-agglutinin staining of cell membranes. Morphometric analysis was performed with a computer-based system. Vic was calculated from Dmin and Dmaj celldiameters using a cylindrical cell-shape approximation.

\section{Results}

L-NAME-treated-mice developed hypertrophy (weightindexed LVMass $4.1 \pm 0.4$ for L-NAME vs. $2.2 \pm 0.3 \mu \mathrm{g} / \mathrm{g}$ for placebo, $\mathrm{p}<0.001$ ). Vic (from histology) was substantially higher in L-NAME-treated-animals $\left(19.4^{*} 10^{3}\right.$, IQR $917.1^{*} 10^{3} \mu \mathrm{mm}^{3}$ vs. $10.7^{*} 10^{3}$, IQR $9.3^{*} 10^{3} \mu \mathrm{mm}^{3}$; $\mathrm{p}<0.0001$ ), while Dmaj/Dmin was smaller (3.4 vs. 4.2, $\mathrm{p}<1 \mathrm{e}-7)$, compared to controls. $\tau$ ic was significantly higher in L-NAME-treated animals $(0.453 \pm 0.10$ vs. 0.234 $\pm 0.06, \mathrm{p}<0.0001)$. $\tau$ ic increased significantly from baseline to 7 -weeks in animals treated with L-NAME $(\mathrm{p}<0.0001)$ (Figure 1). $\tau$ ic strongly correlated with the minor cell diameter $(\mathrm{r}=0756, \mathrm{P}<0.001)$, Vic $(\mathrm{r}=0.875$, $\mathrm{r}<0.001$ ) (Figure 1), and more weakly with the major cell-diameter $(r=0.478, p=0.02)$. ic also correlated with weight-indexed LVMass $(\mathrm{r}=0.71, \mathrm{p}<0.001)$. $\tau$ ic demonstrated an increase from baseline to 7 -week $(0.177$ \pm 0.15 ), which follows the increase of LVmass (39.43 $\pm 36.6 \mu \mathrm{g} / \mathrm{g})$ in the same interval $(\mathrm{r}=0.69, \mathrm{p}<0.001)$.

\section{Conclusions}

Quantification of the intra-cellular lifetime of water ( $\tau$ ic) by MRI provides a robust non-invasive estimation of cell volume changes, validated here against Vic and direct morphological measurements. tic correlated more strongly with Dmin than Dmaj, reflecting the fact that the dependence $\tau$ ic on Dmax is weak for cylindrical shapes with Dmax/Dmin 4. Dmin was the shape 
Figure-1

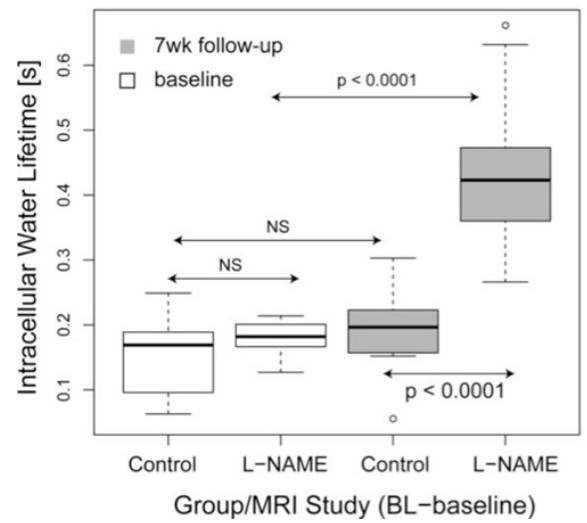

Figure-2

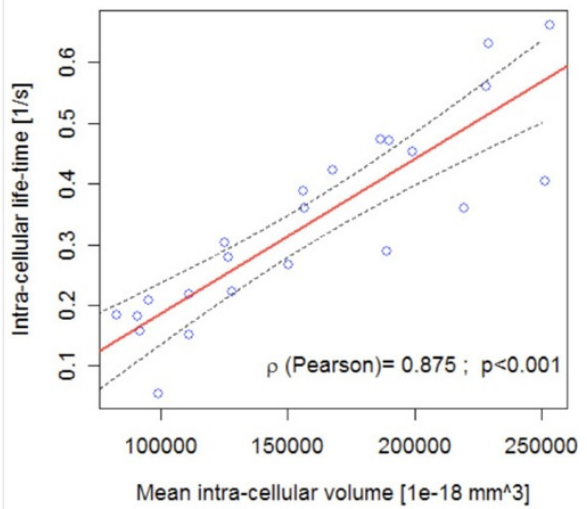

Figure 1 Baseline and 7-week Cell-LifeTIME in control and L-NAME treated-animals. Figure-2: Correlation: intra-cellular volume by histology and Cell-LifeTIME by MRI.

parameter that changes most with hypertension and cell-hypertrophy. This novel MRI-based measure of cell volume may become useful to assess early adverse cellular remodeling in several cardiac conditions.

\section{Funding}

Supported by the American Heart Association (AHA 11POST5550053) and the National Institutes of Health/ NHLBI (1R01HL090634-01A1).

\section{Author details}

${ }^{1}$ Internal Medicine, State University of Campinas, Campinas, Brazil. ${ }^{2}$ Medicine, Brigham and Women's Hospital, Boston, MA, USA. ${ }^{3}$ Radiology, Brigham and Women's Hospital, Boston, MA, USA.

Published: 1 February 2012

doi:10.1186/1532-429X-14-S1-010

Cite this article as: Coelho-Filho et al: MRI based non-invasive detection of cardiomyocyte hypertrophy and cell-volume changes. Journal of Cardiovascular Magnetic Resonance 2012 14(Suppl 1):010.

\section{Submit your next manuscript to BioMed Central} and take full advantage of:

- Convenient online submission

- Thorough peer review

- No space constraints or color figure charges

- Immediate publication on acceptance

- Inclusion in PubMed, CAS, Scopus and Google Scholar

- Research which is freely available for redistribution 